Research article

\title{
Factors influencing predator roadkills: The availability of prey in road verges
}

\author{
Carmo Silva $^{\mathrm{a}, \mathrm{b}, *}$, M. Paula Simões ${ }^{\mathrm{a}, 1}$, António Mira ${ }^{\mathrm{a}, \mathrm{b}}$, Sara M. Santos ${ }^{\mathrm{a}, \mathrm{b}}$ \\ ${ }^{a}$ Instituto de Ciências Agrárias e Ambientais Mediterrânicas, Universidade de Évora, Pólo da Mitra, 7002-554, Évora, Portugal \\ ${ }^{\mathrm{b}}$ Unidade de Biologia da Conservação, Departamento de Biologia, Universidade de Évora, Pólo da Mitra, 7002-554, Évora, Portugal
}

\section{A R T I C L E I N F O}

\section{Keywords:}

Carnivores

Owls

Rabbit

Road verges

Small mammals

Snakes

\begin{abstract}
A B S T R A C T
Road mortality is the most noticeable effect of roads on wildlife. Road verges may provide important refuges for small mammals and rabbits, particularly when roads cross intensive agricultural or grazed areas. In these circumstances, the increasing use of verges by prey species may attract predators to road surroundings increasing the risk of roadkill. The aim of this study was to quantify the role of prey availability (small mammals and rabbits) on predator road casualties, taking into account road and surrounding landscape characteristics. We analyzed this effect on different predator species, such as, snakes, owls and mammal carnivores. The study took place in a $10 \mathrm{~km}$ stretch of a National Road (EN4) in southern Portugal. Relationships among predator mortality and explanatory variables (prey abundance, landscape characteristics, and road verge features) were evaluated using Multivariate Redundancy Analysis (RDA) followed by a variation partitioning. Our results show that, although landscape features explained most of the mortality variation, the prey availability was also very important. Roadkills of Montpellier snake and Egyptian mongoose are strongly associated with wild rabbit abundance on verges, while mortality of stone marten, barn owl and tawny owl is related with wood mouse abundance, Mediterranean forest (montado) density, and verge shrub density. Implications for verge management and implementation of mitigation actions are discussed. We suggest vegetation removal in verges to decrease shelter and food availability for prey, and/or the promotion of habitat for prey in areas distant from roads.
\end{abstract}

\section{Introduction}

Road networks are common landscape elements worldwide and have been increasing in the last decades (Coffin, 2007; van der Ree et al., 2015). However, they have strong negative impacts on wildlife populations (Coffin, 2007; Fahrig and Rytwinski, 2009) such as habitat fragmentation, barrier to movement and to gene flow, and mortality through vehicle collisions (van der Ree et al., 2015). Road mortality is the most direct negative road-associated effect on several vertebrate species (e.g. Fahrig and Rytwinski, 2009; Ceia-Hasse et al., 2018). It is widely acknowledged that road casualties are responsible for killing and injuring millions of animals of different species (Forman and Alexander, 1998; Coffin, 2007; Carvalho and Mira, 2011; D'Amico et al., 2015). In fact, mortality due to vehicle collisions has probably overtaken hunting as the primary direct cause of vertebrate mortality due to human activities during the last decades (Forman and Alexander, 1998). Although roadkills can have minimal effects on populations of abundant species, like rodents and sparrows (Forman and Alexander,
1998; Seiler, 2003), they are considered one of the most important causes of mortality for some predators (Seiler, 2003), such as the Iberian lynx Lynx pardinus (Rodriguez and Delibes, 2004), and the wolf Canis lupus (Lovari et al., 2007). Thus, roadkills can contribute to an increase of the extinction risk of long-lived species with small populations occurring in close proximity to roads, like many predators (Row et al., 2007; Grilo et al., 2012).

The factors influencing the spatial pattern of predator roadkills have been largely studied in the past decades. These include animal abundance and distribution (Seiler, 2003; Grilo et al., 2009), species behavior (Gomes et al., 2009; Grilo et al., 2009), traffic levels and vehicle speed (Colino-Rabanal et al., 2011), landscape patterns (Carvalho and Mira, 2011; Colino-Rabanal et al., 2011; Grilo et al., 2015), and road and verge characteristics (e.g. Gomes et al., 2009; Barrientos and Bolonio, 2009; Santos et al., 2013). Road verges can have indirect negative impacts on predator populations by enhancing roadkills. For instance, a higher concentration of small mammals on road verges might attract predators to roads, thus increasing the risk of being road-

\footnotetext{
* Corresponding author. Instituto de Ciências Agrárias e Ambientais Mediterrânicas, Universidade de Évora, Pólo da Mitra, 7002-554, Évora, Portugal.

E-mail address: carmoms@uevora.pt (C. Silva).

${ }^{1}$ Deceased 15 January 2018.
} 
killed (Bellamy et al., 2000; Barrientos and Bolonio, 2009). Actually, in intensively farmed/grazed or urbanized areas, road verges and hedgerows are the only remaining habitat for small mammals (Bellamy et al., 2000; Santos et al., 2007; Ruíz-Capillas et al., 2013b). Moreover, several studies reported a higher density of small mammals on road verges, in comparison with adjacent areas (Sabino-Marques and Mira, 2011; Ascensão et al., 2012; Ruíz-Capillas et al., 2013a,b). Nonetheless, studies focusing on the influence of prey abundance on verges on the likelihood of predator roadkills are still rare or very specific. For instance, Barrientos and Bolonio (2009) reported higher polecat (Mustela putorius) roadkills in road sections with more rabbits (Oryctolagus $\mathrm{cu}$ niculus), when compared with sections with no polecat mortality. Although these authors focused on the role of prey availability and attempted to quantify its importance on predator casualties, only two species (the rabbit and the polecat), were involved in their study. Also, Ruíz-Capillas et al. (2013a) studied how the proximity to motorways affected the activity of mammalian predators and their main prey, but without a mortality assessment of predators.

Our study aims to quantify the influence of prey availability in road verges (small mammal and rabbit abundance) on predator roadkills, including snakes, owls and mammal carnivores, taking into account the characteristics of road verges and of surrounding landscape. We predict that predator roadkills increase in areas with higher abundances of small mammals and rabbits. To our knowledge, this is the first study aiming to assess the effect of prey availability on road verges on such a diversity of predators. Our results will provide useful information to improve road verge management, in order to reduce the negative impacts of linear infrastructures.

\section{Materials and methods}

\subsection{Study area}

Our study took place in southern Portugal (Évora region) on a $10 \mathrm{~km}$ stretch of National Road 4 (EN4), a major road located in the main terrestrial transportation corridor in the country (Fig. 1). The road connects Montemor-o-Novo and Arraiolos municipalities, is on average $12 \mathrm{~m}$ wide, with two traffic lanes and partially paved verges (1-2 $\mathrm{m}$ wide). The verges are partially fenced $(65 \%)$ on both sides of the road and the traffic volume is moderate (4181 vehicles day ${ }^{-1}$, on average; EP, 2005).

The studied road stretch crosses agricultural areas (including vineyards and olive groves, cereal crops and meadows), and typical Mediterranean woodlands, locally known as montado (open savannah
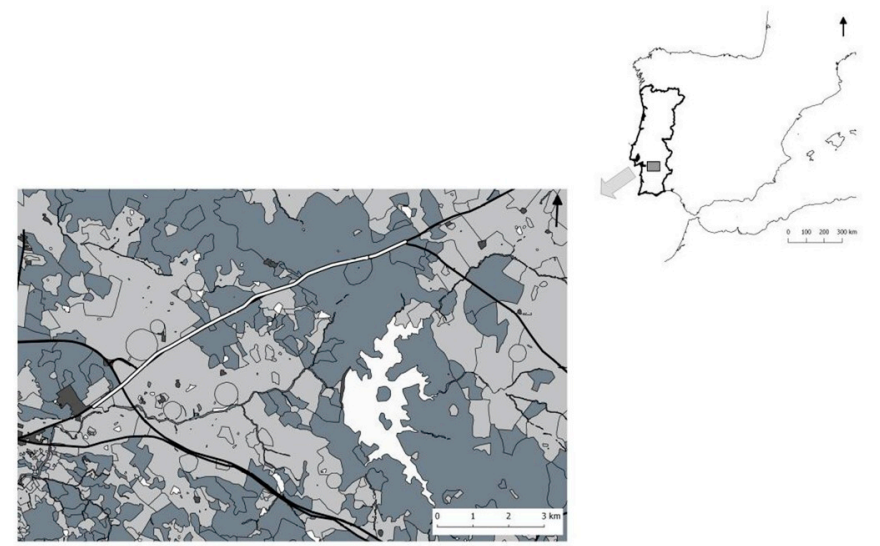

Fig. 1. Map of the surveyed road (white line) and its location in Portugal and Iberian Peninsula. Forested areas are depicted in dark grey, agricultural areas in light grey, water reservoirs in white and other roads in black (source: land uses were obtained through interpretation of aerial photos (year 2005) and field surveys during previous projects; Quantum GIS 2.18.18). like multi-use system dominated by holm and/or cork oak trees (PintoCorreia, 1993)). The topography is mainly plain, with altitude ranging from 100 to $200 \mathrm{~m}$.

The climate is typically Mediterranean, with dry and hot summers, and cold and wet winters. During the study period (2007), the average air temperature was $15.3^{\circ} \mathrm{C}$ (with an average maximum of $32.9^{\circ} \mathrm{C}$ in July and an average minimum of $3.8^{\circ} \mathrm{C}$ in January), while monthly average precipitation ranged from $0 \mathrm{~mm}$ in August to $97.2 \mathrm{~mm}$ in February (IPMA, 2018).

\subsection{Predator roadkill survey}

The $10 \mathrm{~km}$ road stretch was surveyed from January to December (2007) for road fatalities of snakes, owls and wild mammal carnivores. Surveys were performed daily by one experienced observer driving a car at $20-40 \mathrm{~km} / \mathrm{h}$, early in the morning. Road-killed animals were collected and identified to species, and their location was recorded in a GPS unit, with $5 \mathrm{~m}$ accuracy (see Santos et al., 2013 for details). We assume that persistence and detectability rates were high because the high survey frequency, the high observer experience, the low car speed $(<50 \mathrm{~km} / \mathrm{h})$, and the high body mass of target species $(>100 \mathrm{~g})$ all contribute to reduce counting biases (Santos et al., 2016). We are thus confident that the roadkill numbers used in our analyses are an accurate sample of predator mortality in our study area.

\subsection{Explanatory variables}

For analysis purposes, the surveyed road stretch was divided into forty $250 \mathrm{~m}$ length segments, hereafter designated as sampling units (SU). Each SU was characterized considering the number of predator roadkills (response variables) and three sets of explanatory variables: prey abundance (PREY), landscape characteristics (LAND), and road verge features (VERG), which are likely to influence predator roadkills (e.g. Barrientos and Bolonio, 2009; Carvalho and Mira, 2011).

Aboveground small mammals, fossorial rodents and rabbits were used as surrogates of prey abundance due to their abundance in the study area and their importance in the diet of many Mediterranean predators (e.g. Cramp, 1994; Padial et al., 2002; Pleguezuelos et al., 2007; Ferreira, 2012). The timing of surveys was adjusted to the peak abundance and activity periods of each taxa to minimize false absences. Aboveground small mammals were captured along the entire road stretch using Sherman live traps baited with oats and sardine. Traps were placed alternately along both road verges, at $50 \mathrm{~m}$ intervals, in a total of 200 trapping points. Surveys were conducted during the last week of November 2007, on four consecutive nights, and traps were checked every day at sunrise. Captured small mammals were identified to species and marked with a fur clip, which allowed individual identification. Afterwards, animals were released at the site of capture. The number of captures at each SU was used as estimates of abundance of wood mouse Apodemus sylvaticus (AP_SYL), Algerian mouse Mus spretus (M_SPRET), and white-toothed shrew Crocidura russula (C_RUSS). Species with less than five captured individuals (brown rat, Rattus norvegicus and black rat, Rattus rattus) and all recaptures were discarded from analyses.

The abundance of Mediterranean pine vole Microtus duodecimcostatus (M_DUO) was assessed through soil mound counting in May 2007 (Santos et al., 2009) on a $250 \mathrm{~m}$ line transect along each verge of each SU. Soil mounds distancing less than $3 \mathrm{~m}$ were considered as belonging to the same colony. The abundance of pine voles was estimated through the number of colonies per SU.

The abundance of European rabbit Oryctolagus cuniculus (O_CUN) was assessed with ten road transects (five on each direction) done by car, driving at $30-40 \mathrm{~km}$ per hour, and counting the number of rabbits on a $20 \mathrm{~m}$ width band on each road verge. Surveys were performed during May and June 2007, between 6 and 8 a.m., the periods of maximum annual abundance and daily activity, respectively (Díez 
Table 1

Response and explanatory variables according to group set, their acronyms, description and descriptive statistics per SU.

\begin{tabular}{|c|c|c|c|c|}
\hline Variables set & Acronyms & Description & Range & Mean $\pm S D$ \\
\hline \multirow[t]{6}{*}{ Response variables } & M_FOIN & Number of stone marten (Martes foina) roadkills & {$[0 ; 1]$} & $0.15 \pm 0.36$ \\
\hline & H_ICH & Number of Egyptian mongoose (Herpestes ichneumon) roadkills & {$[0 ; 2]$} & $0.12 \pm 0.40$ \\
\hline & S_ALU & Number of tawny owl (Strix aluco) roadkills & {$[0 ; 3]$} & $0.47 \pm 0.71$ \\
\hline & T_ALB & Number of barn owl (Tyto alba) roadkills & {$[0 ; 3]$} & $0.20 \pm 0.61$ \\
\hline & M_MON & Number of Montpellier snake (Malpolon monspessulanus) roadkills & {$[0 ; 4]$} & $0.40 \pm 0.84$ \\
\hline & E_SCA & Number of ladder snake (Rhinechis scalaris) roadkills & {$[0 ; 3]$} & $0.40 \pm 0.71$ \\
\hline \multirow[t]{5}{*}{ Prey availability (PREY) } & AP_SYL & Abundance of wood mouse (Apodemus sylvaticus) & {$[0 ; 3]$} & $0.78 \pm 0.95$ \\
\hline & M_SPRET & Abundance of Algerian mouse (Mus spretus) & {$[0 ; 9]$} & $3.25 \pm 2.22$ \\
\hline & C_RUSS & Abundance of white-toothed shrew (Crocidura russula) & {$[0 ; 5]$} & $1.12 \pm 1.32$ \\
\hline & M_DUO & Abundance of Mediterranean pine vole (Microtus duodecimcostatus) & {$[0 ; 21]$} & $2.73 \pm 3.94$ \\
\hline & O_CUN & Abundance of European rabbit (Oryctolagus cuniculus) & {$[0.00 ; 5.80]$} & $0.68 \pm 1.39$ \\
\hline \multirow[t]{7}{*}{ Landscape (LAND) } & CROP_M $^{\mathrm{a}}$ & Proportion of crops and meadows & {$[0.00 ; 100]$} & $0.34 \pm 0.36$ \\
\hline & $\mathrm{ORCH}^{\mathrm{a}}$ & Proportion of olive groves, orchards and vine & {$[0.00 ; 0.80]$} & $0.12 \pm 0.22$ \\
\hline & MONT_S ${ }^{\mathrm{a}}$ & Proportion of sparse montado (tree canopy cover: $10-50 \%$ ) & {$[0.00 ; 1.00]$} & $0.21 \pm 0.31$ \\
\hline & MONT_D ${ }^{\mathrm{a}}$ & Proportion of dense montado (tree canopy cover: $50-100 \%$ ) & {$[0.00 ; 1.00]$} & $0.32 \pm 0.40$ \\
\hline & D_WCÖU ${ }^{\mathrm{a}}$ & Shortest distance to water courses (m) & {$[2.75 ; 22.22]$} & $16.37 \pm 3.88$ \\
\hline & D_RES ${ }^{\mathrm{a}}$ & Shortest distance to water reservoirs (m) & {$[9.60 ; 19.56]$} & $13.93 \pm 2.44$ \\
\hline & $\mathrm{SDI}^{\mathrm{a}}$ & Landscape diversity index & {$[0.00 ; 0.55]$} & $0.30 \pm 0.16$ \\
\hline \multirow[t]{6}{*}{ Road verge (VERG) } & DSHRUB_SM & Dominance of small shrubs (1: present in $<3$ sites; 2 : present in $\geq 3$ sites) & {$[1 ; 2]$} & - \\
\hline & L_RUB & Length of elm-leaf shrub along each road segment (m) & {$[0 ; 293]$} & $69.00 \pm 95.15$ \\
\hline & P_CULV & Presence/absence of culverts & {$[0 ; 1]$} & - \\
\hline & VERG_W & Class of road verge width $(1:<5 \mathrm{~m} ; 2:>5 \mathrm{~m})$ & {$[1 ; 2]$} & - \\
\hline & N_FENCE & Proportion of road segment without fences on both sides & {$[0 ; 1.00]$} & $0.05 \pm 0.20$ \\
\hline & 1_FENCE & Proportion of road segment with fences only on one side & {$[0 ; 1.00]$} & $0.29 \pm 0.40$ \\
\hline
\end{tabular}

a - Variables transformed (see text).

et al., 2005). The mean number of animals observed at each SU was used as estimates of rabbit abundance.

Landscape characteristics were computed in $250 \mathrm{~m}$ and $500 \mathrm{~m}$ buffers centered on the road, from an original land use map obtained through interpretation of aerial photographs (year 2005) and validated through field surveys. These distances were chosen to sample variation of land uses adjacent to road verges. After an exploratory analysis (Spearman correlation tests), land uses computed in $250 \mathrm{~m}$ buffers presented higher average correlation with predator mortality, and thus were chosen for analyses. At each SU, land uses within 250-m buffers were accounted as the proportion of crops and meadows (CROP_M); orchards, including olive groves, vines and other orchards (ORCH); dense montado (MON_D); and sparse montado (MON_S). Landscape heterogeneity was assessed through the Patch Structural Shannon's Diversity Index (SDI; Rempel, 2008). Distances to main water courses (D_WCOU) and water reservoirs (D_RES) were measured from the midpoint of each SU (Table 1). All landscape derived variables were computed with ArcGIS 9.2 (ESRI, 2004).

Road verge features, measured for each SU, included average verge width (VERG_W), average dominance of small shrubs (DSHRUB_SM) from measurements made at the small mammal trapping sites, and the length of elm-leaf blackberry Rubus ulmifolius (L_RUB). It was also measured the proportion of SU without fences (N_FENCE) or with fences on one side only (1_FENCE); and presence of culverts (P_CULV). Due to the low variability in measured values, VERG_W was recoded in two classes ( 1 - up to $5 \mathrm{~m}$; and 2 - larger than $5 \mathrm{~m}$ ); and DSHRUB_SM was also converted in a two-category variable ( 1 - presence in $<3$; and 2 - presence in $\geq 3$ of the five sampling points at each SU; Table 1).

\subsection{Data analysis}

Before the main data analyses, we evaluated the adequacy of our sample size for each predator species $(n=40)$ using the pseudo multivariate dissimilarity-based standard error (MultSE; Anderson and Santana-Garcon, 2015). This tool evaluates if community precision significantly changes from one sample size to another by determining whether the confidence intervals overlap (Anderson and SantanaGarcon, 2015). The minimum number of samples to attain precision in predator community sampling is decided when the multivariate standard error start to level out (Anderson and Santana-Garcon, 2015). In our data set, the precision of the predator community is attained at $\mathrm{n}=31$, thus supporting an adequate sample size (Supplementary Material: Figure SM1).

In order to achieve normality and reduce the effects of extreme values, land use proportions (CROP_M, ORCH, MON_D and MON_S) were Arcsine transformed, while SDI, D_WCOU and D_RES were log ( $\mathrm{x}$ +1 ) transformed (Zuur et al., 2007). All explanatory variables were standardized to unit variance (Legendre and Legendre, 2012).

The influence of the different sets of explanatory variables on predator mortality was evaluated with a Multivariate Redundancy Analysis (RDA), which allowed the simultaneous evaluation between each predator species and explanatory variables. Following this, a variation partitioning (Borcard et al., 1992) was applied so we could understand the single and shared effects of the three explanatory variable sets and quantify the individual contribution of prey abundance for predator roadkills.

Data exploration suggested short gradients in explanatory variables and thus, RDA is advisable as it is likely that species-environment relationships are mostly linear (Zuur et al., 2007). Rare predator species (found in $\leq 10 \%$ of sampling sites) were not considered for analyses. At a first step, RDA was performed separately for each of the three sets of explanatory variables (PREY, VERG and LAND) and then for all three sets combined (TOTAL). We used a backward stepwise selection with permutation tests to select the most important explanatory variables within each variable set, defining 0.10 as the significance level for variable removal (Zuur et al., 2007). Within each variable set, collinearity was assessed by computing the variance inflation factors (VIF): variables showing VIF $>5$ were discarded (Zuur et al., 2007). The statistical significance of RDA models (group sets and TOTAL model), of separate canonical axes and of terms were assessed with pseudo-F permutation tests (999 permutations; Borcard et al., 2011; Legendre et al., 2011). The three models were then used as a basis for the 
partition of ecological variation (Borcard et al., 1992, 2011).

Analyses were done with package 'Vegan' (Oksanen et al., 2018) and function 'multSE' (Anderson and Santana-Garcon, 2015), within R 2.6.0 (R Development Core Team, 2007).

\section{Results}

\subsection{General results}

We recorded 86 wild predator roadkills belonging to 13 species. Stone marten (Martes foina), Egyptian mongoose (Herpestes ichneumon), tawny owl (Strix aluco), barn owl (Tyto alba), Montpellier snake (Malpolon monspessulanus), and ladder snake (Rhinechis scalaris) were the species with most fatalities ( $\geq 5$ roadkills each). Other less frequent predators included the red fox (Vulpes vulpes), western polecat (Mustela putorius), weasel (Mustela nivalis), European badger (Meles meles), little owl (Athene noctua), and horseshoe whip snake (Hemorrhois hippocrepis).

We recorded 208 small mammal captures, including the Algerian mouse $(n=130)$, white-toothed shrew $(n=45)$, wood mouse $(\mathrm{n}=31)$, black rat $(\mathrm{n}=1)$ and brown rat $(\mathrm{n}=1)$. The Mediterranean pine vole was detected in $31 \mathrm{SU}(77.5 \%)$ out of a total of 40 , and the mean number of presence signs per SU varied between 0 and 21 . Rabbits were recorded in $21 \mathrm{SU}(52.5 \%)$ and the mean number of individuals per SU varied from 0 to 5.8 (Table 1 ).

\subsection{Predator roadkills and variable sets}

The Redundancy Analysis (RDA) included AP_SYL ( $F=4.42$, $P=0.001)$ and $O_{-}$CUN $(F=4.09, P=0.019)$ from the PREY variable set; SDI $(\mathrm{F}=6.06, P=0.001)$, D_RES $(\mathrm{F}=3.66, \mathrm{~F}=P=0.002)$ and MONT_D (F $=3.67, P=0.001$ ) from the LAND variable set; and DSHRUB_SM $(\mathrm{F}=2.24, P=0.024)$ and $\mathrm{L}_{-} R U B(\mathrm{~F}=2.07, P=0.072)$ from the VERG variable set. All partial RDA models were statistically significant $(P<0.05$; Table 2$)$. The first two canonical axes were significant for PREY and LAND models $(P<0.01)$, but not for VERG $\left(\mathrm{P}>0.05\right.$; Table 3). The amount of explained variation (Adjusted $\mathrm{R}^{2}$ ) for the TOTAL model was $32.0 \%$ (Table 4). The first axis accounted for $20.5 \%$ of species variation, while the second axis explained $14.4 \%$, both highly significant $(\mathrm{P}<0.01$; Table 3 ). All VIF values were $<2$ (partial and total RDA models).

The contribution of each variable set to the variation of each predator road-killed is shown in Table 5. Total variation explained was particularly high for Egyptian mongoose and Montpellier snake (H_ICH, $65.2 \%$, and M_MON, 63.9\%, respectively). PREY was the most important set contributing to explain road fatalities of barn owl (T_ALB,

Table 2

Summary results of partial RDA models for the three explanatory variable sets (PREY, LAND and VERG): Expl. Variation (\%): adjusted explained variation (Adjusted $\mathrm{R}^{2}$ ) of each model; Model $\mathrm{F}$ test: pseudo-F test for RDA model; P: significance of respective pseudo-F tests; Variable $\mathrm{F}$ test: pseudo-F test for each explanatory variable within each model.

\begin{tabular}{|c|c|c|c|c|c|c|}
\hline Set & $\begin{array}{l}\text { Expl. } \\
\text { variation (\%) }\end{array}$ & $\begin{array}{l}\text { Model } \\
\text { F test }\end{array}$ & $\mathrm{P}$ & $\begin{array}{l}\text { Explanatory } \\
\text { variables }\end{array}$ & $\begin{array}{l}\text { Variable F } \\
\text { test }\end{array}$ & $\mathrm{P}$ \\
\hline \multirow[t]{2}{*}{ PREY } & 14.3 & 4.252 & 0.002 & O_CUN & 4.0885 & 0.019 \\
\hline & & & & AP_SYL & 4.4155 & 0.001 \\
\hline \multirow[t]{3}{*}{ LAND } & 21.0 & 4.465 & 0.001 & MONT_D & 3.6731 & 0.001 \\
\hline & & & & D_RES & 3.6614 & 0.002 \\
\hline & & & & SDI & 6.0606 & 0.001 \\
\hline \multirow[t]{2}{*}{ VERG } & 5.6 & 2.154 & 0.015 & DSHRUB_SM & 2.2417 & 0.024 \\
\hline & & & & L_RUB & 2.0664 & 0.072 \\
\hline
\end{tabular}

Table 3

Results of significance of canonical axes for the three partial models (PREY, LAND and VERG) and TOTAL model. Axis: identification of constrained axis; $F$ test: pseudo-F test for significance for each constrained axis of RDA model; P: significance of respective pseudo-F tests.

\begin{tabular}{llll}
\hline Set & Axis & F test & P \\
\hline \multirow{2}{*}{ PREY } & Axis 1 & 4.5755 & 0.009 \\
& Axis 2 & 3.9284 & 0.005 \\
LAND & Axis 1 & 8.7156 & 0.001 \\
& Axis 2 & 4.0947 & 0.003 \\
VERG & Axis 1 & 2.2432 & 0.126 \\
& Axis 2 & 2.0649 & 0.070 \\
TOTAL & Axis 1 & 12.1115 & 0.001 \\
& Axis 2 & 8.5346 & 0.001 \\
\hline
\end{tabular}

Table 4

Summary results of total RDA model (TOTAL): Expl. Variation (\%): adjusted explained variation (Adjusted $\mathrm{R}^{2}$ ) of each model; Model $\mathrm{F}$ test: pseudo-F test for RDA model; P: significance of respective pseudo-F tests; Variable F test: pseudo$\mathrm{F}$ test for each explanatory variable within the model.

\begin{tabular}{llllll}
\hline $\begin{array}{l}\text { Expl. variation } \\
(\%)\end{array}$ & $\begin{array}{l}\text { Model } \\
\text { F test }\end{array}$ & $\mathrm{P}$ & $\begin{array}{l}\text { Explanatory } \\
\text { variables }\end{array}$ & $\begin{array}{l}\text { Variable F } \\
\text { test }\end{array}$ & $\mathrm{P}$ \\
\hline \multirow{2}{*}{32.0} & \multirow{2}{*}{3.652} & 0.001 & O_CUN & 5.1529 & 0.007 \\
& & AP_SYL & 5.5650 & 0.001 \\
& & MONT_D & 3.4305 & 0.002 \\
& & D_RES & 2.1398 & 0.041 \\
& & SDI & 6.1986 & 0.001 \\
& & DSHRUB_SM & 0.9949 & 0.435 \\
& & L_RUB & 1.8688 & 0.107 \\
\hline
\end{tabular}

Table 5

Components of constrained variation (\%) for each predator species of partials (variable sets) and total RDA.

\begin{tabular}{lllll}
\hline Species & PREY & LAND & VERG & Total \\
\hline Egyptian mongoose & 27.8 & 23.2 & 26.7 & 65.2 \\
Stone marten & 8.2 & 37.6 & 16.3 & 44.0 \\
Tawny owl & 12.3 & 27.5 & 14.0 & 31.1 \\
Barn owl & 33.1 & 24.1 & 2.4 & 49.3 \\
Montpellier snake & 19.7 & 49.8 & 2.9 & 63.9 \\
Ladder snake & 11.0 & 0.5 & 0.4 & 11.7 \\
\hline
\end{tabular}

33.1\%) and Egyptian mongoose (H_ICH, 27.8\%). However, LAND set explained most of the mortality variation of other predators, particularly the Montpellier snake (M_MON, 49.8\%) and stone marten (M_FOIN, 37.6\%). The VERG set often had the lowest contributions for road-killed species variation $(0.40-26.7 \%)$.

Fig. 2 shows the RDA biplot of predator species and explanatory variables from all sets combined (TOTAL). A strong positive association was found for both owls (T_ALB and S_ALU) and the stone marten (M_FOIN) with AP_SYL, and to a lesser extent to MONT_D and DSHRUB_SM. On the other hand, a strong negative association was found between the mortality of these three predator species and SDI. Higher number of fatalities of the Montepelier snake (M_MON) and Egyptian mongoose (H_ICH) were associated with higher abundance of rabbits (O_CUN). Mortality of these two predator species also tended to occur near water reservoirs (negative association with D_RES). Higher mortality of the ladder snake (E_SCA) was positively associated with the abundance of elm-leaf shrubs in road verges (L_RUB).

The pure effect of LAND set was the main contributor to all predator roadkill variation $(13.9 \%)$, followed by the pure effect of PREY $(8.3 \%)$. The pure effect of VERG was the lowest (1.7\%) and the joint effect of variable sets was lower than $5 \%$ in all analyses (Fig. 3). 


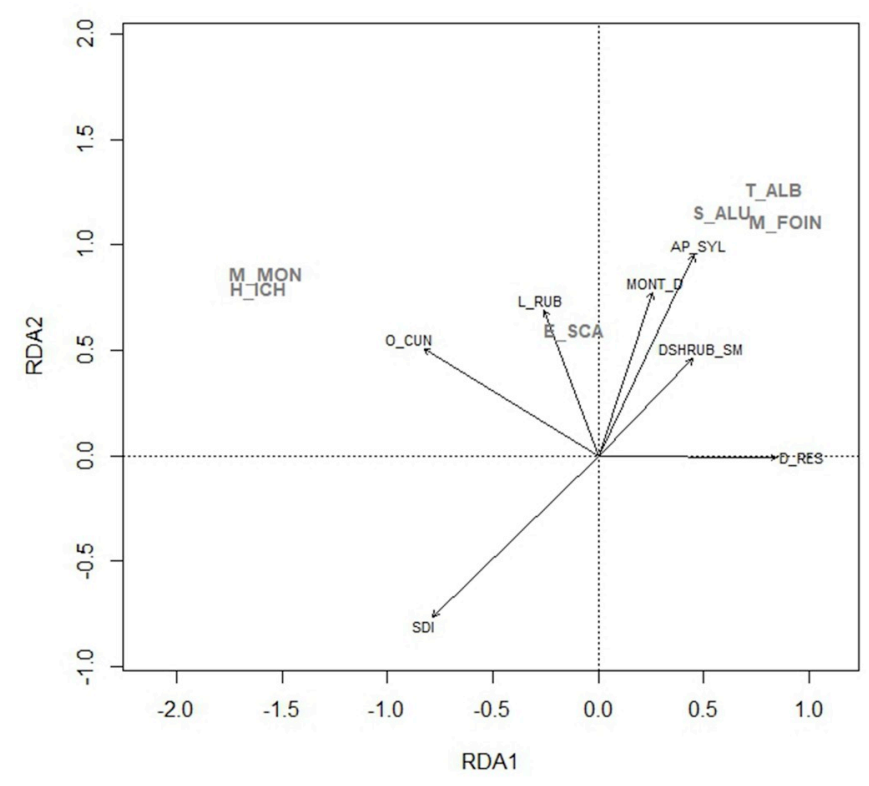

Fig. 2. Ordination biplot for the first two axes of total RDA. Explanatory variables are represented by black arrows and response variables (predator species) by bold grey acronyms (see Table 1 for variables acronyms; source: $\mathrm{R}$ Development Core Team, 2007).

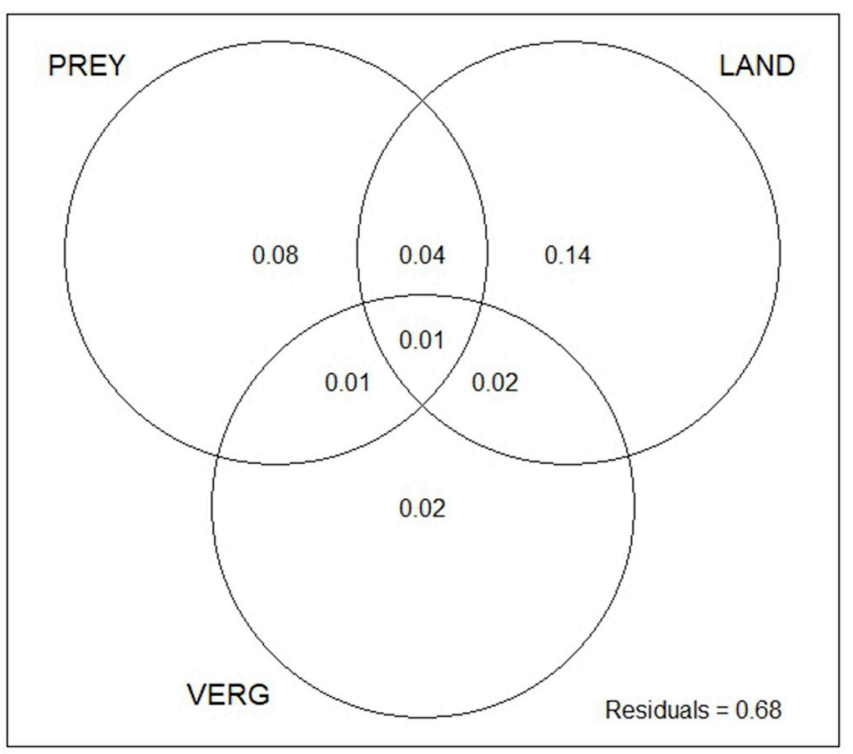

Fig. 3. Proportion of variation explained in RDA for predator roadkills by each set of explanatory variables (Adjusted $\mathrm{R}^{2}$ ). PREY: prey abundance; VERG: road verge features; LAND: landscape characteristics (source: $\mathrm{R}$ Development Core Team, 2007).

\section{Discussion}

To our knowledge, this is the first study attempting to quantify the relative contribution of prey availability on the verges for predator roadkills, considering simultaneously several prey species and different predator groups.

We consider that the objectives of the work have been achieved, as our results support the initial prediction that prey abundance on road verges is one of the major causes of predator roadkills. For the species analyzed, this was evident for all mammal carnivores, all owls and one snake.

We must highlight the strong association between wood mouse and/ or rabbit abundances and casualties of most predator species, which is in accordance with the importance of both species in the diet of several predators. The wood mouse is reported as a significant item in the diet of barn owl (e.g. Taylor, 2003), tawny owl (Kirk, 1992; Cramp, 1994), stone marten (Padial et al., 2002), and ladder snake (Pleguezuelos et al., 2007). In turn, the strong association of rabbit, a key prey in Mediterranean ecosystems (Delibes-Mateos et al., 2007), with Egyptian mongoose and Montepelier snake fatalities, concurs with the high importance of this species in the diet of both predators (Pleguezuelos and Brito, 2008b; Ferreira, 2012). This association is also evident for other carnivores' species in Mediterranean regions; Barrientos and Bolonio (2009) also found a higher number of polecat roadkills in areas with higher abundance of rabbits.

Although predator attraction to areas with high prey abundance is mostly explained by easily available food resources, small mammal burrows are also reported to attract some species, like snakes, which can use them as resting sites or hibernacula (Burger et al., 1988). However, our results give little support to this hypothesis, since we did not find any significant relation between the abundance of fossorial voles, the prey with the largest subterranean galleries, and snake or any other predator mortality.

Road verge characteristics are referred to modulate the probability of wildlife roadkills (Forman and Alexander, 1998). However, the road verge features we studied showed a weak overall influence on predator mortality, except for carnivores and tawny owl. This might partially reflect the low verge variability along our study road. Nevertheless, both owl and stone marten roadkills were associated with sections with high cover of small shrubs in verges. For the carnivores, it is likely that, by providing refuge, shrub cover promotes their use of roadside and therefore increases the likelihood of being road-killed (Clevenger et al., 2001; Seiler, 2003). Moreover, by reducing the visibility of drivers, high shrub cover increases vehicle collision risk, as suggested by Grilo et al. (2009). Particularly, increased tawny owl mortality on road sections with this feature might be related to its hunting behavior, since this species may catch prey among the shrub interspaces (Cramp, 1994).

Besides prey abundance on road verges, the present study also highlights the high proportion of global predator roadkill variation explained by the landscape features, which agrees with results of other studies (Gomes et al., 2009; Grilo et al., 2009; Carvalho and Mira, 2011). Roadkills tend to occur in road sections running through high quality habitats or between species preferred habitats, thus in areas of high species abundance (Seiler, 2003). We found higher predator roadkills in road sections crossing areas of dense montado when compared with other land uses, especially for stone marten and owls. This is also in accordance with other studies referring high number of casualties in roads crossing montado for stone marten (Grilo et al., 2009), and tawny owl (Gomes et al., 2009), for which wooded areas are preferred habitats (e.g. Cramp, 1994; Ruiz-González et al., 2008). Ladder snakes are among the most road-killed species from each predator group of our study and also are commonly found in montados (Pleguezuelos and Brito, 2008a, b). So, the predictable higher abundances of these species on montado agree with their higher fatalities found on road segments crossing this habitat. Moreover, as common in other snakes, ladder snakes are also attracted to paved roads at night to thermoregulate, increasing the risk of roadkills (e.g., D'Amico et al., 2015).

Casualties of some predators, particularly stone marten and owls, tended to be low in areas of heterogeneous landscape (higher Patch Structural Shannon's Diversity Index). In our study site, increasing landscape heterogeneity can be interpreted as a surrogate of an increasing habitat mosaic among montado and open agricultural areas, mostly annual crops and pastures. Considering that most predators require large home ranges (e.g. Schoener, 1968; Gittleman and Harvey, 1982), the low mortality observed might reflect a preference for continuous montado areas (with low heterogeneity), thus confirming the importance of low fragmentation for wooded habitat specialists (Pita et al., 2009). 


\subsection{Implications for conservation and management}

Our results suggest that, besides landscape features, prey abundance on road verges significantly increases the risk of a wide variety of predators being killed. Our results should be considered in global or specific predator conservation programs. Despite none of the confirmed predator species found in the present study is classified as endangered in Portugal or worldwide, some of them, like the barn owl and the polecat (registered but not analyzed), are declining in Europe, being roadkills one of the major causes for this trend (Taylor, 2003; Fernandes et al., 2008). Moreover, our results may have strong implications for understanding road fatalities of endangered predators in southern Iberia, like the Iberian lynx, for which roads are an increasingly important cause of non-natural mortality (Ferreras et al., 1992; Rodriguez and Delibes, 2004). For this species, high rabbit abundance on road verges may have a serious impact since it is an important driver for lynx space use and movements (Palomares et al., 2001). Lynx attraction to road surroundings acting as supplementary feeding areas may jeopardize the great effort spent on current and future Iberian lynx conservation programs.

To reduce the likelihood of predator roadkills, we suggest the regular vegetation cutting in verges to decrease shelter and food availability for rabbits and small mammals, therefore lowering their abundance on roadside (Sabino-Marques and Mira, 2011). Additionally, the removal of tall herbs and shrubs will increase visibility and the likelihood of drivers and predators being aware of each other, potentially decreasing the mortality risk of predators. Even though predators (and prey) might also be aware of approaching cars through light and noise, the removal of vegetation may increase the awareness of the road itself by some species. This management might be more profitable than soil mowing, since mowing also facilitates rabbit warren and small mammal burrow construction, thus increasing shelter.

Vegetation removal may, however, be incompatible with the increasingly recognized road verge role, as biodiversity refuge (e.g. Koyanagi et al., 2009; Sabino-Marques and Mira, 2011) even for prey species of conservation concern (Santos et al., 2007). The trade-offs between these two opposite effects must be properly evaluated in advance of any roadkill mitigation planning, for both new and existing roads. Therefore, alternatively, a more effective option would be the promotion of patches of suitable habitat for prey (mosaics of shrubs and tall grass patches) in areas distant from roads, particularly from those sections crossing intensive agricultural or grazed land thus avoiding prey concentration on roadside environments.

\section{Declarations of interest}

None.

\section{Acknowledgements}

We thank to Filipe Carvalho, Lena Marques, Nelson Varela, Sandra Alcobia, Cláudia Encarnação, Ilaria Campana, Edgar Gomes and Dr. Hélder Cortes for helping during the fieldwork. Thanks to Pedro Salgueiro, Ana Galantinho, Carlos Godinho, Luís Gomes, Denis Medinas, Vânia Neves, Giovanni Manghi and José Herrera for the support during the data analysis and the writing. We also thank J. Tiago Marques and Nuno M. Pedroso for the English revisions.

This work was supported by the Fundação para a Ciência e Tecnologia [POPCONNECT project PTDC/AAG-MAA/0372/2014] and by the LIFE Programme of the European Union [LIFE LINES project LIFE14 NAT/PT/001081].

\section{Appendix A. Supplementary data}

Supplementary data to this article can be found online at https:// doi.org/10.1016/j.jenvman.2019.06.083.

\section{Ethical approval}

All applicable international, national, and/or institutional guidelines for the care and use of animals were followed.

\section{Data availability}

The datasets generated during and/or analyzed during the current study are available from the corresponding author on reasonable request.

\section{References}

Anderson, M.J., Santana-Garcon, J., 2015. Measures of precision for dissimilarity-based multivariate analysis of ecological communities. Ecol. Lett. 18, 66-73.

Ascensão, F., Clevenger, A.P., Grilo, C., Filipe, J., Santos-Reis, M., 2012. Highway verges as habitat providers for small mammals in agrosilvopastoral environments. Biodivers. Conserv. 21, 3681-3697.

Barrientos, R., Bolonio, L., 2009. The presence of rabbits adjacent to roads increases polecat road mortality. Biodivers. Conserv. 18 (2), 405-418. https://doi.org/10. 1007/s10531-008-9499-9.

Bellamy, P.E., Shore, R.F., Ardeshir, D., Treweek, J.R., Sparks, T.H., et al., 2000. Roads verges as habitats for small mammals in Britain. Mamm Rev. 30 (2), 131-139. https://doi.org/10.1046/j.1365-2907.2000.00061.x.

Borcard, D., Gillet, F., Legendre, P., 2011. Numerical Ecology with R. Springer, New York.

Borcard, D., Legendre, P., Drapeu, P., et al., 1992. Partialling out the spatial components of ecological variation. Ecology 73 (3), 1045-1055. https://doi.org/10.2307/ 1940179.

Burger, J., Zappalorti, R.T., Gochfeld, M., Boarman, W., Caffrey, M., Doig, V., Garber, S., Mikovsky, M., Safina, C., Saliva, J., et al., 1988. Hibernacula and summer dens of pine snakes (Pituophus melanoleucus) in the New Jersey pine barrens. J. Herpetol. 22, 425-433.

Ceia-Hasse, A., Navarro, L.M., Borda-de-Água, L., Pereira, H.M., 2018. Population persistence in landscapes fragmented by roads: disentangling isolation, mortality, and the effect of dispersal. Ecol. Model. 375, 45-53.

Carvalho, F., Mira, A., 2011. Comparing annual vertebrate road kills over two time periods, 9 years apart: a case study in Mediterranean farmland. Eur. J. Wildl. Res. 57, 157-174. https://doi.org/10.1007/s10344-010-0410-0.

Clevenger, A.P., Chruszcz, B., Gunson, K.E., et al., 2001. Drainage culverts as habitat linkages and factors affecting passage by mammals. J. Appl. Ecol. 38, 1340-1349. https://doi.org/10.1046/j.0021-8901.2001.00678.x.

Coffin, A.W., 2007. From roadkill to road ecology: a review of the ecological effects of roads. J. Transp. Geogr. 15, 396-406.

Colino-Rabanal, V.J., Lizana, M., Peris, S., 2011. Factors influencing wolf Canis lupus roadkills in Northwest Spain. Eur. J. Wildl. Res. 57, 399-409.

Cramp, S. (Ed.), 1994. Handbook of the Birds of Europe, the Middle East and North Africa - Volume IV: Terns to Woodpeckers. Oxford University Press, USA.

D'Amico, M., Román, J., de los Reyes, L., Revilla, E., 2015. Vertebrate road-kill patterns in Mediterranean habitats: who, when and where. Biol. Conserv. 191, 234-242.

Delibes-Mateos, M., Redpath, S.M., Angulo, E., Ferreras, P., Villafuerte, R., et al., 2007. Rabbits as a keystone species in southern Europe. Biol. Conserv. 137, 149-156. https://doi.org/10.1016/j.biocon.2007.01.024.

Díez, C., Pérez, J.A., Prieto, R., Alonso, M.E., Olmedo, J.A., et al., 2005. Activity patterns of wild rabbit (Oryctolagus cuniculus L.1785) under semi-freedom conditions during autumn and winter. Wildl Biol Pract 1 (1), 41-46. https://doi.org/10.2461/wbp. 2005.1.6.

EP, 2005. Recenseamento de Tráfego - Évora. Estradas de Portugal, E.P.E.

ESRI, 2004. ArcGIS 9. Environmental Systems Research Institute, Inc., New York.

Fahrig, L., Rytwinski, T., 2009. Effects of roads on animal abundance: an empirical review and synthesis. Ecol. Soc. 14, 1-20.

Ferreras, P., Aldama, J.J., Beltrdn, J.F., Delibes, M., et al., 1992. Rates and causes of mortality in a fragmented population of Iberian lynx Felis pardina Temminck, 1824. Biol. Conserv. 61, 197-202. https://doi.org/10.1016/0006-3207(92)91116-A.

Fernandes, M., Maran, T., Tikhonov, A., Conroy, J., Cavallini, P., Kranz, A., Herrero, J., Stubbe, M., Abramov, A., Wozencraft, C., et al., 2008. Mustela putorius. In: IUCN 2010. IUCN Red List of Threatened Species, Version 2010.4. http://www. iucnredlist.org, Accessed date: 9 February 2011.

Ferreira, C., 2012. European rabbit research in the Iberian Peninsula: state of the art and future perspectives. Eur. J. Wildl. Res. 58, 885-895.

Forman, R.T.T., Alexander, L.E., 1998. Roads and their major ecological effects. Annu Rev. Ecol. Systemat. 29, 207-231.

Gittleman, J.L., Harvey, P.H., 1982. Carnivore home-range size, metabolic needs and ecology. Behav. Ecol. Sociobiol. 10, 57-63. https://doi.org/10.1007/BF00296396.

Gomes, L., Grilo, C., Silva, C., Mira, A., et al., 2009. Identification methods and deterministic factors of owl roadkill hotspot locations in Mediterranean landscapes. Ecol. Res. 24 (2), 355-370. https://doi.org/10.1007/s11284-008-0515-z.

Grilo, C., Bissonette, J.A., Santos-Reis, M., et al., 2009. Spatial-temporal patterns in Mediterranean carnivore road casualties: consequences for mitigation. Biol. Conserv. 142, 301-313. https://doi.org/10.1016/j.biocon.2008.10.026.

Grilo, C., Ferreira, F.Z., Revilla, E., 2015. No evidence of a threshold in traffic volume affecting road-kill mortality at a large spatio-temporal scale. Environ. Impact Assess Rev. 55, 54-58. 
Grilo, C., Sousa, J., Ascensão, F., Matos, H., Leitão, I., et al., 2012. Individual spatial responses towards roads: implications for mortality risk. PLoS One 7 (9), e43811. https://doi.org/10.1371/journal.pone.0043811.

IPMA, 2018. Instituto Português do Mar e da Atmosfera, IP, Portugal. Climatic report for 2007. Available: http://www.ipma.pt accessed 20.12.18.

Kirk, D.A., 1992. Diet changes in breeding tawny owls (Strix aluco). J. Raptor Res. 26 (4), 239-242.

Koyanagi, T., Kusumoto, Y., Yamamoto, S., Okubo, S., Takeuchi, K., et al., 2009. Historical impacts on linear habitats: the present distribution of grassland species in forest-edge vegetation. Biol. Conserv. 142 (8), 1674-1684. https://doi.org/10.1016/ j.biocon.2009.03.002.

Legendre, P., Legendre, L., 2012. Numerical Ecology, third ed. Elsevier, Amsterdam.

Legendre, P., Oksanen, J., ter Braak, C.J.F., 2011. Testing the significance of canonical axes in redundancy analysis. Meth Ecol Evol 2, 269-277.

Lovari, S., Sforzi, A., Scala, C., Fico, R., 2007. Mortality parameters of the wolf in Italy: does the wolf keep himself from the door? J. Zool. 272, 117-124.

Oksanen, J., Blanchet, F.G., Friendly, M., Kindt, R., Legendre, P., McGlinn, D., Minchin, P.R., O'Hara, R.B., Simpson, G.L., Solymos, P., Stevens MHH, M., Szoecs, E., Wagner, H., 2018. Vegan: Community Ecology Package. R package version 2.5-1. https:// CRAN.R-project.org/package $=$ vegan.

Padial, J.M., Avila, E., Gil-Sánchez, J.M., et al., 2002. Feeding habitats and overlap among red fox (Vulpes vulpes) and stone marten (Martes foina) in two Mediterranean mountain habitats. Mamm. Biol. 67, 137-146. https://doi.org/10.1078/1616-504700021.

Palomares, F., Delibes, M., Revilla, E., Calzada, J., Fedriani, J.M., et al., 2001. Spatial ecology of Iberian lynx and abundance of European rabbits in south-western Spain Wildl. Monogr. 148, 1-36.

Pinto-Correia, T., 1993. Threatened landscape in Alentejo, Portugal: the Montado and other agro-silvo pastoral systems. Landsc. Urban Plan. 24, 43-48. https://doi.org/10. 1016/0169-2046(93)90081-N.

Pita, R., Mira, A., Moreira, F., Morgado, R., Beja, P., et al., 2009. Influence of landscape characteristics on carnivore diversity and abundance in Mediterranean farmland. Agric. Ecosyst. Environ. 132, 57-65. https://doi.org/10.1016/j.agee.2009.02.008.

Pleguezuelos, J.M., Brito, J., 2008a. Elaphe scalaris (schinz, 1822). In: Loureiro, A Ferrand de Almeida, N., Carretero, M.A., Paulo, O.S. (Eds.), Atlas dos Anfíbios e Répteis de Portugal. Instituto da Conservação da Natureza, Lisboa, pp. 172-173.

Pleguezuelos, J.M., Brito, J., 2008b. Malpolon monspessulanus. In: Loureiro, A., Ferrand de Almeida, N., Carretero, M.A., Paulo, O.S. (Eds.), Atlas dos Anfíbios e Répteis de Portugal. Instituto da Conservação da Natureza, Lisboa, pp. 180-181.

Pleguezuelos, J.M., Fernández-Cardenete, J.R., Honrubia, S., Feriche, M., Villafranca, C., et al., 2007. Correlates between morphology, diet and foraging mode in the Ladder Snake Rhinechis scalaris (Schinz, 1822). Contrib. Zool. 76 (3), 179-186.

R Development Core Team, 2007. R: A Language and Environment for Statistical Computing. R Foundation for Statistical Computing, Vienna, Austria. http://www.Rproject.org.R R.Cited.20.Nov.2007.

Rempel, R., 2008. Patch Analyst 4 for ArcGIS. Centre for Northern Forest Ecosystem
Research (Ontario Ministry of Natural Resources). Ontario. http://flash.lakeheadu. ca/ rrempel/patch/index.html, Accessed date: 15 May 2008.

Rodriguez, A., Delibes, M., 2004. Patterns and causes of non-natural mortality in the Iberian lynx during a 40-year period of range contraction. Biol. Conserv. 118, 151-161. https://doi.org/10.1016/j.biocon.2003.07.018.

Row, J.R., Blouin-Demersa, G., Weatherhead, P.J., et al., 2007. Demographic effects of road mortality in black ratsnakes (Elaphe obsoleta). Biol. Conserv. 137, 117-124. https://doi.org/10.1016/j.biocon.2007.01.020.

Ruiz-Capillas, P., Mata, C., Malo, J., 2013a. Community response of mammalian predators and their prey to motorways: implications for predatory-prey dynamics. Ecosystems 16, 617-626.

Ruiz Capillas, P., Mata, C., Malo, J., 2013b. Road verges are refuges for small mammal populations in extensively managed Mediterranean landscapes. Biol. Conserv. 158, 223-229.

Ruiz-González, A., Rubines, J., Berdión, O., Gómez-Moliner, B.J., et al., 2008. A noninvasive genetic method to identify the sympatric mustelids pine marten (Martes martes) and stone marten (Martes foina): preliminary distribution survey on the northern Iberian Peninsula. Eur. J. Wildl. Res. 54, 253-261. https://doi.org/10. 1007/s10344-007-0138-7.

Sabino-Marques, H., Mira, A., et al., 2011. Living on the verge: are roads a more suitable refuge for small mammals than streams in Mediterranean pastureland? Ecol. Res. 26, 277-287. https://doi.org/10.1007/s11284-010-0781-4.

Santos, S.M., Lourenço, R., Mira, A., Beja, P., 2013. Relative effects of road risk, habitat suitability, and connectivity on wildlife roadkills: the case of tawny owls (Strix aluco). PLoS One 8, e79967.

Santos, S.M., Mathias, M.L., Mira, A., Simões, M.P., et al., 2007. Vegetation structure and composition of road verge and meadow sites colonized by Cabrera vole (Microtus cabrerae Thomas). Pol. J. Ecol. 55 (3), 481-493.

Santos, S.M., Mira, A., Mathias, M.L., et al., 2009. Using presence signs to discriminate between similar species. Integr. Zool. 4, 258-264. https://doi.org/10.1111/j.17494877.2009.00163.x.

Santos, R.A.L., Santos, S.M., Santos-Reis, M., Figueiredo, A.P., Bager, A., Aguiar, L.M.S., Ascensão, F., 2016. Carcass persistence and detectability: reducing the uncertainty surrounding wildlife-vehicle collision surveys. PLoS One 11 (11), e0165608. https:// doi.org/10.1371/journal.pone.0165608.

Schoener, T.W., 1968. Sizes of feeding territories among birds. Ecology 49 (1), 123-141.

Seiler, A., 2003. The Toll of the Automobile: Wildlife and Roads in Sweden. Doctoral thesis. Swedish University of Agriculture Sciences.

Taylor, I., 2003. Barn Owls: Predator-Prey Relationships and Conservation. Cambridge University Press, Cambridge.

van der Ree, R., Smith, D.J., Grilo, G., 2015. Chapter 1: the ecological effects of linear infrastruxture and traffic: challenges and opportunities of rapid global growth. In: van der Ree, R., Smith, D.J., Grilo, G. (Eds.), Handbook F Road Ecology. John Wiley \& Sons, Ltd.

Zuur, A.F., Ieno, E.N., Smith, G.M., et al., 2007. Analysing Ecological Data. Springer, US. 